\title{
Chinese Philosophy and Universal Values in Contemporary China ${ }^{1}$
}

\author{
John MAKEHAM*
}

\begin{abstract}
Consistent with its growing economic, political and military might, China wants due recognition by and engagement with the global community of nations. This aspiration is complicated by the fact that Chinese political leaders and intellectuals continue to struggle with how "Chinese values" fit with "universal values", and whether there is a single global modernity or whether there are multiple modernities and multiple - perhaps competing - universal values. In this paper I examine how some prominent Chinese philosophers are engaging with these issues, despite the fact that in 2013 the topic of "universal values" was prohibited as a discussion topic in universities on the mainland.
\end{abstract}

Keywords: universal values, tianxia, Chen Lai, Xu Jilin, Ge Zhaoguang

\section{Kitajska filozofija in univerzalne vrednote v sodobni Kitajski}

\section{Izvleček}

Kitajska si v skladu s svojo naraščajočo gospodarsko, politično in vojaško močjo želi ustreznega priznanja in sodelovanja z globalno skupnostjo narodov. Zaplete pri tem prizadevanju povzroča dejstvo, da se kitajski politični voditelji in intelektualci še vedno spopadajo $\mathrm{z}$ vprašanjem, kako se »kitajske vrednote« ujemajo $\mathrm{z} »$ univerzalnimi vrednotami« in ali obstaja enotna svetovna modernost, ali pa je nemara več modernosti in več - morda v medsebojnem tekmovanju - univerzalnih vrednot. V tem članku proučujem, kako se nekateri vidni kitajski filozofi soočajo s temi vprašanji, čeprav je bila leta 2013 na univerzah na celini tema »univerzalnih vrednot« kot razpravna tema prepovedana.

Ključne besede: univerzalne vrednote, tianxia, Chen Lai, Xu Jilin, Ge Zhaoguang

1 A shorter French version of this essay will be published in "Philosophie chinoise et valeurs universelles en Chine contemporaine" in Anne Cheng (ed.), Que penser en Chine aujourd'hui? (Paris: Editions Gallimard), in press.

* John MAKEHAM, La Trobe University. Email address: j.makeham@latrobe.edu.au

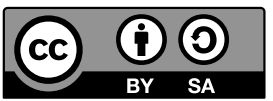


Consistent with its growing economic, political and military might, China wants due recognition by and engagement with the global community of nations. This aspiration is complicated by the fact that Chinese political leaders and intellectuals continue to struggle with how "Chinese values" fit with "universal values", and whether there is a single global modernity or whether there are multiple modernities and multiple — perhaps competing — universal values. This essay examines how some prominent Chinese philosophers and intellectuals are engaging with these issues, despite the fact that in 2013 the topic of "universal values" was prohibited as a discussion topic in universities on the mainland. Key Chinese intellectuals introduced include Chen Lai, Zhao Tingyang, Xu Jilin, Ge Zhaoguang, Guo Qiyong and a range of younger academics associated with the Kang Clique (Kang dang), as well as Confucian revivalists who self-consciously identify as so-called "Mainland New Confucians". Attention is also paid to both advocates and critics of attempts to revive the idea of tianxia, "All under Heaven". The essay concludes with a short reflection on whether a new sort of tianxia world order might already be with us.

\section{Background}

The late 1970s and 1980s witnessed the growth of an influential movement in Taiwan and Hong Kong to "Sinicize" (Zhongguohua 中國化) or "indigenize" (bentuhua 本土化) the social sciences, in particular social psychology, anthropology and sociology (Chang 2005). The movement promoted a return to the cultural roots of "being Chinese" and the development of "Sinicized" social and behavioural science approaches to research. In Taiwan, the indigenization process began under the name of "Zhongguohua" (Sinicization) because, in the social sciences, China was regarded as the "local" during the 1980s. The term bentuhua was also adopted to refer to this same idea. By and large, the term Zhongguohua represented the claim that the social sciences (or particular social science disciplines) should be grounded in local/regional culture, experience, and perspectives, where "local/regional" variously refers to a somewhat vague notion of "China" or Chinese society (including Taiwan), or to particular "Huaren 華人” (Sinitic) societies, or to Taiwan. The basic theme of the movement was that Chinese social scientists should be self-conscious, self-critical, and independent (that is, not subordinated to the West) so as to contribute to making the world's social science disciplines more cosmopolitan and globalized through proper acknowledgement being afforded to national and cultural particularities.

By the mid-1980s, however, the term "indigenization" as used in Taiwan came to refer to the process of "Taiwanization" in the cultural and political arenas. 
With the end of martial rule and removal of press restrictions in 1987, and the emergence of Taiwanese cultural nationalism that same decade, renewed interest in Taiwanese history and culture began to consolidate and assert itself in both intellectual and popular discourses. The Kuomindang's 1991 abandonment of its claim to be the legitimate government of all China and the implementation of a democratic electoral system at the national level legitimized political and intellectual interest in a Taiwanese identity. Sinicization gradually lost favour in Taiwan during the 1990s as a consequence of the changing political landscape, ${ }^{2}$ but during the same period the terms "Sinicization" and "indigenization" both found support among anthropologists and psychologists on the mainland (ibid., 245; Qiao 2001; Xu 2001).

It was also in the 1990s that a similar trend gradually became embedded in the field of Chinese philosophy, particularly on the mainland. However, unlike the Sinicization movement in 1970s and 1980s Taiwan, here the goal of recognizing the local was not subordinated to that of introducing a Chinese voice into the discipline of philosophy in order to make the discipline more global and more cosmopolitan and thereby reinforce the discipline's universalist claims. Rather, the case of Chinese philosophy emerged as a response to the perceived threat that the universalist claims of theory posed to the particularity of local cultural identity.

A watershed in this process of development occurred in the early years of the new millennium with the so-called legitimacy of Chinese philosophy debate (Zhongguo zhexue de hefaxing 中國哲學的合法性) (Defoort 2001; Defoort and Ge 2006). Many Chinese academics argued that "Western philosophy" had yet to acknowledge "the legitimacy" of Chinese philosophy and to engage it as an equal partner in dialogue. Others further insisted that the articulation and development of China's philosophical heritage must draw exclusively on the paradigms and norms of China's indigenous traditions, and that paradigms and norms derived from the West, in particular, are not only inappropriate but hegemonic and/or

2 The Democratic Progress Party, formed in 1986, won the presidential elections for the first time in 2000. The ascendancy of the Democratic Progressive Party was accompanied by a deepening movement to "indigenize" political, social, and cultural institutions on the island, in which indigenization (bentuhua) came to function as a type of nationalism that championed the legitimacy of a distinct Taiwanese identity, the character and content of which should be determined by the Taiwanese people. Many proponents of indigenization in Taiwan regard it quite specifically as a project of desinicization: an attempt to remove the yoke of "Chinese" colonial hegemony so that Taiwan's putative native (bentu) identity could be recognized and further nurtured. For these proponents, the role of the Other in the indigenization paradigm is identified with a monolithic conception of China and Chineseness, which is typically portrayed as inimical to the integrity of Taiwanese identity. 
ill-suited to China's national "conditions". For example, writing in 2009, the Hong Kong philosopher Shun Kwong-loi 信廣來 insisted that: "It is by studying Chinese ethical thought on its own terms that we can bring out its more distinctive ideas, which can then be fleshed out and developed without being shaped by agendas set by Western philosophical discussions" (Shun 2009, 476). Shun drew attention to the consequences of the modern default practice of using Western concepts and frameworks for doing comparative work between Chinese and Western philosophies, noting that, "while we see frequent deployment of Western philosophical frameworks in the study of Chinese thought, we rarely encounter the reverse phenomenon, namely, the deployment of Chinese philosophical frameworks in the study of Western thought”. He continues:

... We see engaged discussions of such questions as whether Mozi is a utilitarian, but not whether John Stuart Mill is a Moist or endorses jianai 兼愛. We find debates about whether traditional Chinese thought has a conception of rights but not whether Western traditions have a conception of $l i$ 理. And, more recently, we see debates about whether Confucian ethics is a form of virtue ethics but not about whether Aristotelian ethics is a form of lixue 理學. (ibid., 456-57, 472)

Support for these kinds of concerns was, in turn, bolstered by a robust Confucian-centred Chinese cultural nationalism: a movement based on the ideological conviction that Confucianism is a cultural formation integral to the identity consciousness of the Chinese (Zhonghua 中華) nation.

\section{Universal Values and their Discontents}

Similar views were also raised in the context of guoxue re 國學熱 or National Learning fad that also peaked at the end of the first decade of the new millennium (Makeham 2011). Although definitions of guoxue vary, often considerably, most Chinese scholars seem to favour a broad definition, usually along the lines of "a general collective term for traditional Chinese culture", "traditional Chinese scholarship" or "research on Chinese culture". A major figure in instigating both the legitimacy of Chinese philosophy debate and reviving guoxue is Chen Lai 陳來. He is currently Professor of Philosophy at Tsinghua University and the Dean of Tsinghua University's Guoxue yuan 國學院, which goes by the English name of the Academy of Chinese Learning. In a notable article published in the Guangming ribao in 2010 he wrote: 
Historians long ago pointed out that China's several thousand years of unbroken historical record is unique in the world. The principles informing all social sciences must be subjected to and validated by the test of China's historical experience before their veracity can be proven. The National Learning fever helps people to reflect critically upon the standpoint from which Western culture takes the particular to be the universal; to reflect critically upon the importation or transplantation of Western systems of learning; and, by taking due account of China's experience and China's wisdom, establish a subjectivity for Chinese culture, and promote the equal exchange of the world's many cultures. (Chen 2010)

Other protagonists at the time also expressed concerns about the effects of Western systems of learning in China. For example, some worried that because classical studies - an inalienable part of National Learning - has been reduced to philosophy, philology, history, or anthropology, this had led to methodological confusion and impeded true understanding (Chen 2009, 178). Others despaired that:

The Western system of academic disciplines has led to the breaking up and fragmentation of China's traditional learning. Because of this, guoxue cannot exist and develop as an organic whole. Consequently, it is difficult to guarantee that China's traditional learning and culture can exert a strong influence among the national cultures of the world. (Jiao 2010)

Still others similarly complained that traditional bodies of learning associated with the bibliographic taxonomy of the Four Divisions, the Sibu 四部—classics, histories, masters and collected writings - had not only each been subjected to dislocation, but that the knowledge contained in each had become mere "material" for disciplines introduced from the West (Zhu 2009).

Since then, complaints about Western cultural imperialism have not been the concern of academics alone; concerns about the cultural particularly of so-called universal values have also become a major issue for China's leaders. Consistent with its growing economic, political and military might, China wants due recognition by and engagement with the global community of nations. This aspiration is complicated by the fact that Chinese political leaders and intellectuals continue to struggle with how "Chinese values" fit with "universal values" and global institutions, and whether there is a single global modernity — one perhaps China can shape — or whether there are multiple modernities and multiple — perhaps competing — universal values. ${ }^{3}$

3 To belabour the obvious, the presumption that "multiple modernities" implies "multiple universal values", is problematic, not least because of the implication that universality can be multiple. 
In the wake of the PRC leadership transition to President Xi Jinping in mid-November, 2012, the party-state's hostility to universal values increased notably.

This shift was most evident when Liu Qibao 劉奇葆 became the head of the Publicity Department, which oversees propaganda. Early in 2013, a notice was sent to universities about “seven prohibited topics of discussions" (qi bu jiang 七不講). Universal values topped the list of prohibited topics, and there remains significant reticence about discussing this topic openly.

President Xi Jinping's most important speech on universal values was given at the Central Party School at the end of 2015, in which he berated foreign powers for using Western "universal values" to subvert China's socialist ideology:

Within and beyond the nation, various antagonistic powers are always trying to undermine what our Party stands for. Most damagingly, they plot to get us to cast aside our faith in Marxism and discard our belief in Socialism and Communism. And even some of our comrades within the Party, who haven't clearly perceived the hidden agenda therein, think that since Western "universal values" have endured for several centuries, why shouldn't we identify with them? What's wrong with borrowing some Western political discourse? It won't bring any great harm ... These people thus unwittingly become a cheer squad for Capitalist ideology. (Xi 2016)

In going on to address the topic of strengthening the Party's work on theoretical education, Xi Jinping stressed the need for Party educators to provide clear guidance to students in the Central Party School about the proper way to understand issues such as:

- the scientific nature of "Socialism with Chinese characteristics";

- $\quad$ strengthening and improving Party leadership;

- the scientific content of the values of freedom, democracy and equality; and

- what in the West are called universal values.

Now, it might seem incongruous that values such as freedom, democracy and equality are distinguished from what Xi Jinping refers to as "what in the West are called universal values". Here we need to bear in mind that, already early in 2012, the Party's ideological authorities had proclaimed a set of "core socialist values" (社會主義核心價值), as follows:

\section{National values}

- Prosperity (富强)

- Democracy (民主) 
- Civility (文明)

- Harmony (和諧)

\section{Social values}

- Freedom (自由)

- Equality (平等)

- Justice (公正)

- Rule of law (法治)

\section{Individual values}

- Patriotism (愛國)

- Dedication (敬業)

- Integrity (誠信)

- Friendship (友善)

Collectively, the twelve values are obviously an amalgam of past and present, local and global conceptual ingredients. Oddly, however, there is no hint of just what foundation this motley set of values is rooted in. What is clear from Xi Jinping's comments, however, is that freedom, democracy and equality are not to be identified with their Western namesakes.

\section{Chen Lai}

Despite the explicit criticisms of universal values and the championing of core socialist values, some prominent Chinese academics have not only managed to navigate these dangerous political waters, but have also accrued significant political capital in the process. Chen Lai is perhaps the most prominent example. As noted above, Chen is Professor of Philosophy at Tsinghua University and the Dean of Tsinghua University's Guoxue yuan. He is widely regarded as the foremost specialist of Confucian philosophy in China. In 2018, he was also appointed as a member of the Chinese People's Political Consultative Conference (中國人 民政治協商會議), a national legislative advisory body in the People's Republic of China. This appointment is a strong endorsement by the Party of Chen Lai, and of his approach to the issue of universal and particular values.

In an insightful recent article, intellectual historian Hoyt Cleveland Tillman writes:

In the current political environment, where Chinese particularistic values are lauded and universals are highly suspect, it is impressive that Chen Lai has set forth a synthesis of Confucianism and Marxism in terms 
of their projected universalities. For example, his portrayal of freedom, equality and justice as universally desired goals or values, is grounded in his own account of Confucian moral values; therefore, he is able to propose his case for linking these three values to the political ends of Chinese Socialism and the common good of society, rather than through a Liberal Western discourse on rights. (Tillman 2018, 1276)

Besides approving of Chen Lai's 2014 book, Renxue benti lun 仁學本體論 (Humaneness-based Ontology), the authorities have reportedly praised Chen Lai's approach to discussing universal values. According to Tillman:

The Party-controlled media's embrace of his recent books and articles reinforces the impression that despite its sensitivity to, and policies against, universal values, the Chinese Communist Party still includes members who are not totally opposed to the universal significance of values, but are anxious to re-define those values to accord not only with Chinese tradition (as Chen has done) but also to be compatible to the conditions deemed necessary for continued political control. (ibid., 1284)

Chen Lai is an expert on Neo-Confucian philosophy of the Song (960-1279) and Ming (1368-1644) periods. His self-styled "humaneness-based ontology" is a sophisticated attempt to develop a new ontology, drawing inspiration from a range of thinkers, including the great Neo-Confucian philosopher Zhu Xi 朱喜 (1130-1200). One of Chen's more creative appropriations of Zhu Xi's thought concerns Zhu Xi's account of the unity of the virtues, in which one cardinal virtue, that of humaneness, is foundational for a group of other cardinal virtues. Specifically, these cardinal virtues are the four that the classical Confucian philosopher Mencius (fourth century BC) first clustered as a group: humaneness (ren 仁); doing what is just and one's duty ( $y i$ 義); behaving with decorum ( $l i$ 禮); and wisdom ( $z h i$ 智). What is distinctive in Zhu Xi's account of the unity of these virtues is that humaneness is presented as sustaining and giving rise to the other three virtues.

Chen Lai's creative appropriation was to adapt Zhu Xi's strategy and make humanness the foundation not only of other Confucian virtues, but also of the universal values of freedom (ziyou 自由), equality (pingdeng 平等), and justice (gongzheng 公正) (Chen 2014, 429). 


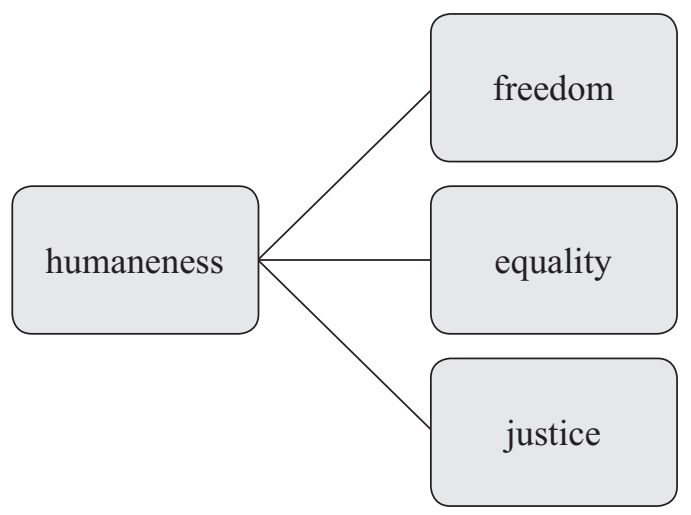

Credit: John Makeham

Chen further seeks to persuade the reader that these four "universal values" are a legacy of the Chinese Confucian tradition, and thus not simply an import from the West. As Tillman notes, this resulting synthesis of values is presented as having advantages over Western programmes of universal values. On the one hand, Chen Lai wants to insist that China's concept of humaneness can embrace the global, because the Chinese concept of humaneness is the essential foundation of all values. On the other hand, he seeks to reject claims that the Western universalistic value of democracy should apply to China (Tillman 2018, 1278).

In a 2015 Renmin ribao article, Chen Lai wrote:

In discussing the particular characteristics of the values of "Chinese" civilization (Zhonghua wenming 中華文明), we cannot attend only to the moral concepts of Chinese culture but must take Western culture as a comparator-in particular the values of modern Western culture-in order to discern the particular characteristics of the values of Chinese civilization. When compared to modern Western values, there are four particular characteristics of the values of Chinese civilization:

- responsibility comes before freedom;

- duty comes before rights;

- the social group comes before the individual person; and

- harmony is esteemed over conflict.

In Western culture and Western values there is a conflict mentality that always seeks to use its own power, and take a self-centred stance to overcome, control and dominate others. Because of this, religious wars throughout Western history are extremely brutal; in contrast, China has never experienced such religious wars. It can indeed be said that the 
cultural origins of the twentieth century's two world wars do no lie in the East. Overall, it can be said that when compared to Western culture and Western values, Chinese culture and Chinese values emphasize harmony over conflict. (Chen 2015a, 7)

Instead of demonstrating how such values of liberty, equality, and justice are actualized or evident in the policies and institutions of the PRC, Chen Lai uses the Singapore model of "Asian values" to implicitly support his case that the Chinese value system can encompass such modern values. He further insists that the core of Asian values is Confucian. In 2015 Chen Lai published the volume, Zhonghua wenming de hexin jiazhi 中華文明的核心價值 (The Core Values of Chinese Civilization). In an appendix to that volume, Chen writes:

Are there new universal values that have been brought forth out of Confucianism itself, values that differ from liberal democratic ones? I think there are. In today's world the most influential ones are undoubtedly what Singapore has called Asian values. Asian values include five main values:

- first the social state is more important than the individual;

- second, the roots of the state are in the family;

- third, the state must respect the individual;

- fourth, harmony is better than conflict at maintaining social order; and

- fifth, there must be peaceful coexistence and complementarity between religions.

I think that if I were to look at this topic of "new universal values" I would naturally think of the example of Singapore. These five principles not only include traditional East Asian values; they also include the new values that have been absorbed from Western civilization over the past century, such as the one stipulating that the state must respect the individual. Actually, Singapore's set of Asian values is a systematic set of values that does not give priority to individualism. This is Singapore's version of modern Asian values, and I think that this is also Singapore's version of the values of modern Confucian civilization, the core of which is not the priority of the individual's right of freedom, but the good of society and the community. (ibid. 2015b, 199-200)

I note in passing that Chen Lai made almost exactly the same comments about Asian values as early as 1998 (ibid. 1998, 12). 


\section{Critiques of the Individual}

Asian values, of course, refers to the cultural relativist claim that many of the political, social and cultural norms of the late twentieth century are Western, and are not universal norms. As such, these Western norms are not more legitimate than alternative norms that could be considered "Asian". Asian values are particularly associated with the communitarian position which advocates that the rights of the community - be it the family or the state-take precedence over those of the individual.

In the Asian values debate in Singapore in the 1990s, the role of the family created a dilemma for Lee Kuan Yew, as it did for many other advocates of "Asian values" at the time. Writing at the end of the 1990s, historian Michael Barr noted that this is because the family is expected to fulfil two contradictory roles:

It needs to be the building block of society and to provide the rationale for the paternalistic state, but it is also expected to be completely - and often humiliatingly - subservient to the needs of the state and the needs of the capitalist economy ... Family-based communitarianism can be and is being used as a tool to support state-focused communitarianism, but this is not its natural function. In their purest forms the two are rivals. In its most extreme form, state-focused communitarianism is a form of totalitarianism that cannot allow any alternative sources of authority or power in society. (Barr 2000, 326, 328)

As it happens, a similar tension has been playing itself out in China over the past decade in a series of ongoing debates between two prominent Chinese philosophers, Guo Qiyong 郭齊勇 and Liu Qingping 劉清平, and their respective supporters (Huang 2017). The debate focuses on the concept of filial piety. Liu Qingping has argued that Confucian philosophy rests on a fundamental paradox: on the one hand, it privileges consanguineous affection, love for family members, and yet and on the other hand, it promotes loving concern for all ${ }^{4}$ (Liu 2003, 23637). As summarized by Hagop Sarkissian, "Liu argues that Confucianism ought to put a more universal ethic at its core and jettison its emphasis on kin relations, paving the way for a new Post-Confucianism, which would value universal care or concern well ahead of filial piety" (Sarkissian 2010, 731).

In response to Liu, Guo Qiyong defended the idea of the mutual non-disclosure of wrongdoings among family members, based on early texts such as the Analects and Mencius. He maintained that this moral principle is grounded in human

$4 \quad$ Liu first developed these views in Liu 2000; 2002. 
nature, and to be found both in the East and West (Guo 2002). In turn, his critics saw this position as supporting the obstruction of justice, in which law-breaking family members are protected from state retribution. ${ }^{5}$ Although Liu and Guo both appeal to the principle of universal values, Guo's position is of particular interest in that it prioritizes the family over the state. Despite this stance, it seems to have had no negative impact on Guo's prominent role in promoting both Confucian philosophy and National Learning in China. ${ }^{6}$

As with Guo Qiyong and Chen Lai, a number of prominent Western scholars who work in the field of Chinese philosophy have also been critical of values that are based on the notion of the atomic individual. In particular, the positions taken by North American comparative philosophers Roger Ames, Henry Rosemont, and Daniel Bell, have lent considerable ballast to the agenda of philosophers such as Chen Lai. I note also that both Ames and Bell now both work at universities in China. Ames and Rosemont object to forms of Western ethical theorizing, such as virtue ethics, in which the individual is the focus. Ames argues that

the language of virtue ethics, in appealing as it does to the vocabulary of agents, acts, generic virtues, character traits, autonomy, motivation, reasons, choice, freedom, principles, consequences, and so on, introduces distinctions that assume a foundational individualism as its starting point. (Ames 2016, 142)

With its deep roots in the classical Greek philosophical narrative, he insists that individualism has become a default, common-sense assumption, if not an ideology. He describes it as having "garnered a monopoly on human consciousness without any serious alternative to challenge it". Instead, he proposes what he calls Confucian role ethics, arguing that it provides a better ethical model ${ }^{7}$ (ibid.). At the heart of Confucian role ethics is "a specific vision of human beings as relational persons constituted by the roles they live rather than as individual selves" (Rosemont and Ames 2016). Rosemont and Ames provide the following illustration:

$5 \quad$ Essays by early participants on both sides of the debate are collected in Guo 2004.

6 It is also worth noting one of the practical outcomes of Guo's "activism". In August 2011, at the twenty-second session of the 11th National People's Congress (NPC), Guo's proposal to restore the system of "mutual concealment" was incorporated into a draft amendment to the Criminal Procedure Law of the People's Republic of China and was approved in March the following year. See Amendment \#188 listed at http://www.npc.gov.cn/npc/dbdhhy/11_5/2012-03/19/content_1715305_9.htm.

7 See also Ames 2010. For a series of essays on "Confucian Role Ethics", see Rosemont and Ames 2016. 
Confucian normativity is defined by living one's family roles to maximum effect ... Lived family roles - mothering, brothering, granddaughtering - are themselves normative standards that, informed as they are by existential embodiment, are much clearer and more concrete than putative moral principles. (ibid.)

This critique of ethical models in which the individual is the foundational unit, is also a key element in the utopian political order proposed by Chinese IR theorist, Zhao Tingyang 趙汀陽. I am, of course, referring to his Tianxia 天下 or “All-under-Heaven" model. Historian Wang Gengwu 王賡武 (Gungwu Wang) describes tianxia as "an abstract notion embodying the idea of a superior moral authority that guided behaviour in a civilized world ... (It) depicts an enlightened realm that Confucian thinkers and mandarins raised to one of universal values, used to determine who was civilized and who was not" (Wang 2013, 133). In his own vision of tianxia, Zhao Tingyang describes the place of the individual as follows:

All-under-Heaven takes the whole world as a single political system that is much greater and higher than a single country or nation/state ... The Chinese system of families, states, and All-under-Heaven-which differs fundamentally from the Western system of individuals, nations and internationals - is often criticized for its neglect of the individual as well as individual rights, but this is a misunderstanding ... There is no Chinese denial of the value of the individual, but rather a denial of the individual to be a political foundation or starting point, because the political makes sense only when it deals with "relations" rather than "individuals", and the political is meant to speak for co-existence rather than a single existence. (Zhao 2006, 34, 33)

Another influential political theorist who takes a similar stance to Ames, Rosemont and Zhao on the status of the individual is Daniel A. Bell. Bell is Dean of the School of Political Science and Public Administration at Shandong University. In his earlier work, Beyond Liberal Democracy: Political Thinking for an East Asian Context (2006), he criticized liberal democracy and the shortcomings of liberal individualism. In his recent and more widely discussed book, The China Model: Political Meritocracy and the Limits of Democracy (2015), Bell's target is electoral democracy and what he calls the tyranny of the majority.

For Bell, the danger of electoral democracy is that irrational and self-interested majorities acting through the democratic process can use their power to oppress minorities and enact bad policies. Sound familiar? In contrast, he argues, the virtue of political meritocracy is that examinations that test for voter competence 
can help to remedy this flaw. As with Chen Lai, Bell also touts Singapore's political meritocracy as a viable alternative to electoral democracy. As for China, he writes:

The leading political idea in China — widely shared by government officials, reformers, intellectuals, and the people at large - is what I call "vertical democratic meritocracy", meaning democracy at lower levels of government, with the political system becoming progressively more meritocratic at higher levels of government. (Bell 2015, xiii)

Bell, of course, has no shortage of detractors. He has been criticized for offering little evidence of meritocracy at work, and no more than a theoretical argument in its defence. Others attack him for presenting a fictional China as a rhetorical platform from which to continue a long-standing debate internal to Western political thought - the debate between communitarianism and liberal democracy. Despite these and many other criticisms, his status as a public intellectual of some note in China has in no way been tarnished.

Mention should also be made of the Chinese philosophy specialist Stephen C. Angle's self-styled "Progressive Confucianism". The case of Angle provides a counterpoint to the anti-individualist stance of Chen Lai, Ames, Rosemont, Zhao, and Bell. According to Angle's Progressive Confucianism

ethical insight leads to progressive political change, which in turn leads to greater realization of our potential for virtue ... The institutions advocated by Progressive Confucians are valued not because of their ancient pedigree but because of their capacity to assist in the realization of the fundamental human virtues that Confucians have valued since ancient times. Social structures that set barriers to the realization of virtue, therefore, need to be critiqued and changed. (Angle 2012, 18, 17)

Despite the fundamental differences with Ames, Rosemont and Zhao on the issue of atomic individuals, Angle is sympathetic to Zhao's normative concept of "All-under-Heaven", because it requires us to "view the world from the perspective of the world". This perspective, Angle argues, "requires us to arrive at the universal world perspective through an inclusive process, rather than universalizing a single perspective" (ibid., 89). Thus human rights and other principles of modern liberal philosophy can be figured as relevant in Confucian philosophy, even if they did not derive from prior Confucian values. Angle's critics, however, argue that on his analysis, Confucianism is "relevant" and "'modern' only to the extent that it can accommodate the values of some form of liberal democracy". In other words, 
Angle continues "to articulate the validity of Confucian ideas in terms shaped almost exclusively by modern European thought and experience” (Jenco, 2017, 6).

\section{Kang Clique}

Over the past decade, a group of younger academics based at various universities in China has also been arguing for the priority of the nation over the individual. This group has become known informally as the Kang Clique (Kang dang 康黨). Several prominent figures associated with the Kang Clique were also participants in a workshop held at East China Normal University in Shanghai in 2011. The transcripts of discussions from the workshop was published two years later under the title, He wei pushi? Shei zhi jiazhi? Dangdai Rujia pushi jiazhi 何謂普世? 誰 之价值? 當代儒家論普世價值 (What is Universal? Whose Values? Contemporary Confucians Discuss Universal Values) (Zeng and Guo 2014).

The name "Kang Clique" derives from the call by some of its more prominent “members" such as Chen Ming 陳明 and Gan Chunsong 干春松 to “return to Kang Youwei". Kang Youwei 康有為 (1858-1927) was a major intellectual and reformer active in the transition between the Qing Empire and the establishment of Republican China. For many Confucian revivalists today, particularly those who self-consciously identify as so-called "Mainland New Confucians" (Dalu xin Rujia 大陸新儒家), Kang had proposed a superior blueprint for nation-building and state-building, at a critical juncture in China's history, as it moved from being an empire to being a nation-state.

Chen Ming, for example, writes that in Kang Youwei's blueprint, "the integrity of the nation and maintenance of the people's livelihood took historical priority over individual rights, constitutional democracy, freedom of belief and other value priorities of the Enlightenment project" (Gan et al. 2104, 25). Here the Enlightenment project refers to the liberal intellectual tradition in modern China. Chen laments that ultimately Kang's vision was highjacked by the agenda set by liberal intellectuals. He continues: "The Enlightenment project and its utopian narrative should only have been chosen if they could have served as a program for salvation; we should not and cannot allow theory to swallow up facts, or means to become ends, but, most unfortunately this where our biggest problems are today" (ibid.). In other words, the utopian visions of Chinese liberals continue to block Kang's blueprint from being realized. For Confucian revivalists such as Chen Ming, a key element in Kang's blueprint was a proposal to make Confucianism the state religion, and this is something that Chen Ming and his colleagues continue to argue for today. 
Kang Youwei is also relevant to the topic of tianxia or "All-under-Heaven". Kang was associated with a lineage of Confucian scholarship known as New Text Confucianism. New Text Confucianism has its origins in the Han dynasty (206 BC220 AD), but was revived and creatively reinterpreted in the nineteenth century. One of the key features of New Text Confucianism is its emphasis on a cyclical view of history, characterized by a three-stage periodization. Kang Youwei transformed this cyclical model into a teleological model of three-stage progress, which culminates in the utopian vision of an "age of universal peace" (taiping shi 太平世) or “great unity” (datong 大同).

As with Chen Lai, Kang attached a particularly high importance to the moral ideal of ren (humaneness). For Kang, ren represents a metaphysical world view; "a moral ideal or value pattern built into the structure of reality" (Chang 1987, 37). Furthermore, Kang's understanding of the moral ideal of ren was teleological. He projected the full realization of ren to a distant but definite point in the future: the "age of universal peace" or "great unity". His vision of this "great unity" amounted to an "all-inclusive universal society, with no room place for the territorial state" (ibid., 62).

\section{Xu Jinlin's New Tianxia}

Another prominent Chinese public intellectual who has also been active in promoting the concept of tianxia as an inclusive political institution that transcends nation-states and nationalism is the Shanghai-based academic, Xu Jilin 許紀霖. In sharp contrast to the "Kang Clique", $\mathrm{Xu}$ is strongly opposed to nationalism. Xu maintains that nationalism can lead to horrific large-scale violence, such as the two world wars. His antidote to nationalism is what he calls the "new tianxia". He describes tianxia in traditional China as "a world spatial imaginary with China's central plains at the core", and claims that the values of this civilizational tradition were universal and humanistic rather than particular and unique to one civilization or culture:

Behind the traditional Chinese empire was a tianxia consciousness for all humanity, a set of universal values that transcended the particular interests of any given dynasty. Their source was the moral way of heaven. These values served as the standard for determining right and wrong throughout All Under Heaven, constrained the behaviour of rulers, and determined the legitimacy of a given dynasty's rule. (Xu 2015) 
He then makes the following comments about post-tianxia China, that is, China of the last one hundred years: "An empire without tianxia consciousness means that the imperial body no longer possesses a soul with universal values and a civilization that puts people at ease. In its place, there is nothing but calculation of the nation-state's self-interest." (ibid.)

Yet if traditional tianxia was so cosmopolitan and universal, how does $\mathrm{Xu}$ explain the age-old distinction between barbarians ( $y i$ 夷) and Chinese (xia 夏), a distinction that has been a consistent hallmark of the notion of tianxia? While acknowledging that people in pre-modern China spoke not just of tianxia but also of the difference between barbarians and Chinese, Xu insists:

In early China, (notions of) "Chinese and barbarian" were completely different from the dichotomies of "China and the West" and "us and them" that today's extreme nationalists are always talking about ... That which determined the distinction between barbarian and Chinese was solely whether or not a civilization was associated with the values of tianxia. Whereas tianxia was absolute, the (categories of) barbarian and Chinese were relative. Whereas blood and race were innate and unchangeable, civilization could be studied and emulated. (ibid.)

He further claims that in traditional China, "tianxia did not belong to one particular race or country" (ibid.).

Despite $\mathrm{Xu}$ Jilin's reputation as a liberal public intellectual strongly opposed to nationalism, some of his discussion of China as a civilizational power invites questions about his vision for a so-called "new tianxia":

If China's goal is not to stop with the construction of the nation-state, but rather to re-establish itself as a civilizational power with great influence in global affairs, then its every word and deed must take universal civilization as its point of departure, and in global dialogue it must have its own unique understanding of universal civilization ... As a great power with global influence, what China must now realize is not just the dream of rejuvenating the nation and the state, but also the re-orientation of its national spirit toward the world. What China needs to reconstruct is not a particularistic culture suited to one country and one people, but rather a civilization that has universal value for all humanity. Values that are "good" for China, particularly the core values that concern our shared human nature, should in the same way be "good" for all humanity. (ibid.) 
The message here is decidedly mixed. On the one hand, $\mathrm{Xu}$ calls for the reconstruction of values that have universal significance for all humanity and not just one culture or society. On the other hand, this aspiration seems to be fundamentally compromised by his other claim that due to China's "own unique understanding of universal civilization", which in turn is grounded in China's pre-modern tradition of tianxia, then China should seek to "re-establish itself as a civilizational power with great influence in global affairs" and reconstruct "a civilization that has universal value for all humanity".

$\mathrm{Xu}$ supports his claim that China is well prepared to "re-establish itself as a civilizational power" by invoking American political scientist Lucian Pye's famous aphorism that "China is a civilization pretending to be a nation-state" (Pye 1992, 232). Xu reinforces this sense of historical destiny by further claiming that "China is a world power. As a nation of the world that bears Hegel's 'world spirit' (Weltgeist) it is only proper that it take responsibility for the world and for the "world spirit' it has inherited. This 'world spirit' is the new tianxia that will emerge in the form of universal values." (Xu, 15)

As for his assertion that "Values that are 'good' for China, particularly the core values that concern our shared human nature, should in the same way be 'good' for all humanity", is its import really much different from that conveyed by Chen Lai's assertion that humaneness is the foundation not only of Confucian values, but also of the universal values of freedom, equality, and justice? After all, from a Confucian perspective, humaneness is an innate quality of our human nature, and so must be good for all humanity.

Indeed, despite the appeal to universal values, in Xu Jilin's notion of new tianxia it seems it is Confucianism that is presented as the authority for determining which values constitute "core values". He explains that, historically, the greatness of Confucianism came from its capacity to transcend the interests of the individual and the dynasty. Today, being above the state, Confucianism "possesses the universal values of tianxia". By insisting that "values that are 'good' for China ... should in the same way be 'good' for all humanity", $\mathrm{Xu}$ is making a case for expanding the range of universal values, but in a way that privileges Confucian values.

China's proponents of tianxia are not without their critics. One of the most important is historian Ge Zhaoguang 葛兆光 of Fudan University:

In recent years, some Chinese scholars have felt that, as China begins its "rise" after several centuries of a world order led by the West, a "tianxia order" or "tianxia-ism" that has its origins in traditional China should be 
deemed a fresh resource for replacing the world order that has been in place since the early modern period (Ge 2014, 161).

Ge points out that these scholars

argue that, on a philosophical level, the Confucian world is a world without borders, one without the distinctions of inner and outer, us and them. It is a world in which all people are treated equally. Accordingly, this tianxia order should be used to replace the current world order.

He warns that if this kind of thinking is not stripped of its core of nationalism (which sees China as the "centre of tianxia") and its attitude of arrogant self-regard, "then it can easily become a new form of chauvinism that claims to have universal relevance under the cover of representations such as 'equality of the multitude of states' and 'all in the four seas are one family"' (ibid., 173).

$\mathrm{Ge}$ is also critical of some of the more radical Confucian revivalists in contemporary China, known as political Confucians or "mainland New Confucians", which includes members of the "Kang clique", contributors to the publication He wei pushi? Shei de jiazhi? Dangdai Rujia pushi jiazhi (discussed above), as well as contributors to a wide range of more recent writings, including the 2016 volume, Zhongguo bixu zai Ruhua: “Dalu xin Rujia” xin zhuzhang 中國必須再 儒化: “大陸新儒家”新主張 (China Must Re-Confucianize: New Proposals by 'Mainland New Confucians'). The fact that a scholar of Ge Zhaoguang's standing in the academic community should devote a 33,000 Chinese character essay (Ge 2017) to critiquing their views, underscores the growing influence of this conservative, and extremely nationalistic, group of ideologues.

In the essay he describes how the Mainland New Confucians feel that to acknowledge universal values is to succumb to "Westernization", and amounts to "self-barbarization" (自我夷狄化). He points out that the idea of "barbarization" is an extremely strong accusation, because it elevates the distinction between Chinese and barbarian from that of a difference in values to that of a clash between the civilized and uncivilized, or even places races and cultures in absolute opposition. I would again note that the distinction between Chinese (華) and barbarian (夷) is very much central to traditional tianxia discourse.

\section{Concluding Remarks}

Chen Lai's creative appropriation of Zhu Xi's philosophy to make humaneness (ren) the foundation not only of Confucian virtues, but also of the universal values 
of freedom, equality, and justice, is without doubt an exercise in hybridization, albeit a highly reductionist and politically calculated hybridization. We will have to wait to see whether an ideological cocktail of Confucian and core socialist values will provide the right formula for a future tianxia world order.

Ge Zhaoguang warns of the following scenario if the concept of tianxia is brought to life:

When imagined versions of the tribute system are taken to be real, and memories of the Celestial Empire are unearthed, then perhaps Chinese culture and national sentiment will turn into a nationalism (or statism) that opposes both global civilization and regional cooperation. Such a development would truly lead to a "clash of civilizations". (Ge 2014, 178)

Or is the future already here? In an article published in Foreign Affairs, sociologist Salvatore Babones describes what he calls the American Tianxia. Let me conclude with his description of the dystopian, brave new world he conjures up:

Today the United States is at the center of a global tianxia. This "American Tianxia" is much more than a state or country, or even an empire. It pervades all areas of life. In today's connected world, Chinese businesses, Russian universities, and even Iranian revolutions are run on American lines. The Islamic State (ISIS) recommends that its fighters use Android devices whereas North Korea's ruling Kim family famously prefers Apple. Many people around the world oppose the United States, its policies, and its president, but they still want to send their children to American universities, invest their money in American companies, and express their opinions on American social networks.

This is not some kind of consumerism run amok. Standing at the center of the global order, the United States has, over the last quarter century, reoriented the way the world - and especially the world's elite-works, plays, and thinks. It has brought them into an international hierarchy in which gaining status requires succeeding within U.S.-centered networks and playing by U.S. rules. And it makes twenty-first century America more powerful than any empire, kingdom, or commonwealth in history. The United States - that is, the country itself-has plenty of hard and soft power. But the United States has limits. The American Tianxia does not. (Balbones 2017) 


\section{References}

Ames, Roger T. 2010. Confucian Role Ethics: A Vocabulary. Hong Kong: Chinese University Press.

Ames, Roger T. 2016. "Theorizing 'Person' in Confucian Ethics: A Good Place to Start." Sungkyun Journal of East Asian Studies 16 (2): 141-62.

Angle, Stephen C. 2012. Contemporary Confucian Political Philosophy. Cambridge: Polity Press.

Babones, Salvatore. 2017. "American Tianxia: When Chinese Philosophy Meets American Power." Foreign Affairs, June 22, 2017. Accessed July 2, 2018. https:/www.foreignaffairs.com/articles/2017-06-22/american-tianxia.

Barr, Michael D. 2000. "Lee Kuan Yew and the "Asian Values' Debate." Asian Studies Review 24 (3): 309-34.

Bell, Daniel A. 2006. Beyond Liberal Democracy: Political Thinking for an East Asian Context. Princeton: Princeton University Press.

—. 2015. The China Model: Political Meritocracy and the Limits of Democracy. Princeton: Princeton University Press.

Chang, Hao. 1987. Chinese Intellectuals in Crisis: Search for Meaning and Order (1890-1911). Berkeley: University of California Press.

Chang, Maukuei. 2005. "The Movement to Indigenize the Social Sciences in Taiwan: Origin and Predicaments." In Cultural, Ethnic, and Political Nationalism in Contemporary Taiwan: Bentuhua, edited by John Makeham, and A-chin Hsiau, 221-60. New York: Palgrave.

Chen, Lai 陳來. 1998. "Shei zhi zeren? He zhong lunli? Cong Rujia lunli kan shijie lunli xuanyan 誰之責任? 何種倫理? ——從儒家倫理看世界倫理 宣言 (Whose Responsibility? What Kind of Ethics? The Declaration toward a Global Ethic Viewed from Confucian Ethics).” Dushu 10: 8-12.

—. 2010. "Ruhe kandai guoxue re 如何看待國學熱 (How Should Guoxue Fever be Regarded?)." Guangming ribao, August 2, 2010. Accessed August 5, 2018. http://culture.china.com.cn/guoxue/2010-08/02/content_20619540.htm.

—. 2014. Renxue benti lun 仁學本體論 (Humaneness-Based Ontology). Beijing: Sanlian Shudian.

—. 2015a. "Chongfen renshi Zhonghua dute jiazhiguan: cong Zhong-Xi bijiao kan 充分認識中華獨特價值觀——從中西比較看 (Fully Recognize the Unique Values of Zhonghua: Comparing China and the West)." Renmin ribao, April 4, 2015.

—. 2015b. Zhonghua wenming de hexin jiazhi 中華文明的核心價值 (The Core Values of Chinese Civilization). Beijing. Sanlian Shudian. 
Chen, Ming 陳明. 2009. “Qidai yu yilü: cong Qinghua Guoxue yuan kan Renda Guoxue Yuan 期待與疑慮: 從清華國學院看人大國學院 (Expectations and Doubts: Looking at Renmin University's Guoxue Institute from the Perspective of the Tsinghua Academy of Chinese Learning)." In Chen Ming, Wenhua Ruxue: sibian yu lunbian 文化儒學: 思辨與論辯 (Cultural Ruxue: Thoughts and Arguments). Chengdu: Sichuan renmin chubanshe.

Defoort, Carine. 2001. "Is There such a Thing as Chinese Philosophy?" Philosophy East and West 51 (3): 393-413.

Defoort, Carine, and Ge Zhaoguang, eds. 2006. "Collection of Articles on the Theme of 'The Legitimacy of Chinese Philosophy'." Contemporary Chinese Thought 37 (1-3).

Gan, Yang 甘陽, et al. 2014. “Kang Youwei yu zhiduhua Ruxue 康有為與制度 化儒學 (Kang Youwei and Institutionalized Confucianism).” Kaifang shidai 5: $12-41$.

Ge, Zhaoguang 葛兆光. 2014. He wei Zhongguo? Jiangyu, minzu, wenhua yu lishi 何為「中國」? 疆域、民族、文化與歷史 (What is China? Territory, Ethnicity, Culture and History). Hong Kong: Oxford University Press.

—. 2017. "Yi xiang tian kai: jin nian lai dalu xin Ruxue de zhengzhi suqiu 異想 天開——近年來大陸新儒學的政治訴求 (A Flight of Fancy: The Political Demands of Mainland New Confucians in Recent Years)." Accessed August 12, 2018. http://www.aisixiang.com/data/104951.html.

Guo, Qiyong 郭齊勇. 2002. “Ye tan 'zi wei fu yin' yu Mengzi lun Shun 也談「子 为父隱」與孟子論舜 (On the Son’s Concealment of His Father's Crime and Mencius's View of Shun)." Zhexue yanjiu 10: 27-30.

—, ed. 2004. Rujia lunli zhengming ji 儒家倫理爭鳴集 (Collection of Essays on the Confucian Ethics Debate). Wuhan. Hubei jiaoyu chubanshe.

Huang, Yong. 2017. "Why an Upright Son Does Not Disclose His Father Stealing a Sheep: A Neglected Aspect of the Confucian Conception of Filial Piety." Asian Studies 1: 15-45.

Jenco, Leigh. 2017. "How should We Use the Chinese Past? Contemporary Confucianism, the 'Reorganization of the National Heritage' and Non-Western Histories of Thought in a Global Age." European Journal of Political Theory 16 (4): 450-69.

Jiao, Guocheng 焦國成. 2010. “Zengshe guoxue wei yiji xueke hen you biyao 增設國學為一級學科很有必要 (On the Need to Add Guoxue to the Level 1 Disciplinary Categories)." Guangming ribao, September 13, 2010.

Liu, Qingping 劉清平. 2000. “Lun Kong-Meng Ruxue de xueqin tuantixing tezheng 論孔孟儒學的血親團體性特徵 (On the Characteristics of Consanguineous Community in Confucius-Mencius Confucianism)." Zhexue men 哲學門 (Philosophy) 1: 80-101. Wuhan: Hubei jiaoyu chubanshe. 
—. 2002. "Meide haishi fubai? Xi Mengzi zhong youguan Shun de liangge anli 美德還是腐敗？析《孟子》中有關舜的两個案例 (Virtue or Corruption? An Analysis of Two Cases of Shun in the Mencius)." Zhexue yanjiu 哲學研 究 (Philosophical Studies) 2: 43-47.

—. 2003. "Filiality versus Sociality and Individuality: On Confucianism as 'Consanguinitism'.” Philosophy East and West 53 (2): 234-50.

Makeham, John. 2011. "The Revival of Guoxue: Historical Antecedents and Contemporary Aspirations." China Perspectives 1: 14-21.

- 2020. "Philosophie chinoise et valeurs universelles en Chine contemporaine." In Que penser en Chine aujourd'hui?, edited by Anne Cheng. Paris: Gallimard. In press.

Pye, Lucian W. 1992. The Spirit of Chinese Politics. Cambridge, MA: Harvard University Press.

Qiao, Jian 喬健 et al., eds. 2001. 21 shiji de Zhongguo shehuixue yu renleixue二 十一世紀的中國社會學與人類學 (Chinese Sociology and Anthropology in the 21st Century). Kaohsiung: Liwen chubanshe.

Rosemont, Henry Jr., and Roger T. Ames. 2016. Confucian Role Ethics: A Moral Vision for the 21st Century? Taipei: National Taiwan University Press.

Sarkissian, Hagop. 2010. "Recent Approaches to Confucian Filial Morality." Philosophy Compass 5 (9): 725-34.

Shun, Kwong-loi. 2009. "Studying Confucian and Comparative Ethics: Methodological Reflections." Journal of Chinese Philosophy 36 (3): 455-78.

Tillman, Hoyt Cleveland. 2018. "China's Particular Values and the Issue of Universal Significance: Contemporary Confucians amidst the Politics of Universal Values." Philosophy East and West 68 (4): 1265-91.

Wang, Gungwu. 2013. Renewal: The Chinese State and the New Global History. Hong Kong: Chinese University Press.

Xi, Jinping 習近平. 2016. “Xi Jinping zai Quanguo Dangxiao gongzuo huiyi shang de jianghua 習近平在全國党校工作會議上的講話 (Xi Jinping's Speech at the Work Conference of the National Party School)." Qiu shi, April 30, 2016. Accessed June 5, 2018. http://www.qstheory.cn/dukan/qs/201604/30/c 1118772415.htm.

$\mathrm{Xu}$, Jilin 許紀霖. 2015. “Xin tianxiazhuyi: chongjian Zhongguo de neiwai zhixu 新天下主義：重建中國的内外秩序 (New Tianxia-ism: Reconstructing China's Internal and External Orders)." Zhishi fenzi luncong 知識分子論 叢 (Intellectuals) 13. Accessed May 30, 2018. http://www.aisixiang.com/ data/91702.html.

$\mathrm{Xu}$, Jieshun 徐杰舜, ed. 2001. Bentuhua: Renleixue de da qushi 本土化: 人類 學的大趨勢 (Indigenenization: The Main Trend in Anthropology). Guangxi: Minzu chubanshe. 
Zeng, Yi 曾亦, and Guo Xiaodong 郭曉東, eds. 2014. He wei pushi? Shei de jiazhi? Dangdai Rujia pushi jiazhi 何謂普世? 誰之价值? 當代儒家論普 世價值 (What is Universal? Whose Values? Contemporary Confucians Discuss Universal Values). Shanghai: Huadong shifan daxue.

Zhao, Tingyang. 2006. "Rethinking Empire from a Chinese Concept 'All-under-Heaven' (Tian-xia, 天下).” Social Identities 12 (1): 29-41.

Zhu, Hanmin 朱漢民. 2009. “Ba wei zhuanjia: guoxue shi yimen xueke 八位專 家: 國學是一門學科 (Eight Experts: Guoxue is a Discipline).” Guangming ribao, October 12, 2009. 